\title{
Using of geogebra software to improve understanding of vector and kinematic concepts in online physics course
}

\author{
${ }^{1}$ Jeffry Handhika, Mislan Sasono ${ }^{2}$ \\ 1,2 Prodi Pendidikan Fisika, Universitas PGRI Madiun, Kota Madiun 63118, Indonesia \\ e-mail: : jhandhika@unipma.ac.id; mislan@unipma.ac.id
}

\begin{abstract}
This research aims to improve understanding of vector and kinematics concepts with Geogebra software in online learning (online using e-Learning UNIPMA (e-LMA). The method used in this research is a descriptive conducted on four students who took fundamental physics for the 2019/2020 academic year. The research steps are described as follows 1) creating a profile and analyzing understanding of vector concepts and kinematics before implementing eLMA, (2) describing the learning process through e-LMA, (3) creating a profile, and analyze students' understanding of vector concepts and kinematics after the implementation of e-LMA. ELMA-assisted learning by integrating materials and assignments with GeoGebra software can improve understanding of vector and kinematic concepts.
\end{abstract}

Keywords: e-LMA, Geogebra, Vector, Kinematics

\section{Penggunaan software geogebra untuk meningkatkan pemahaman konsep vektor dan kinematika Pada Pembelajaran Fisika Secara Online}

\begin{abstract}
Penelitian ini bertujuan untuk meningkatkan pemahaman konsep vektor dan kinematika dengan software Geogebra pada pembelajaran daring (dalam jaringan menggunakan e-Learning UNIPMA (e-LMA). Metode yang digunakan dalam penelitian ini adalah penelitian deskriptif yang dilakukan pada mahasiswa 4 mahasiswa yang mengambil fisika dasar tahun akademik 2019/2020 sejumlah 4 mahasiswa. Langkah-langkah penelitian dijelaskan sebagai berikut 1) membuat profil dan menganalisis pemahaman konsep vektor dan kinematika sebelum menerapkan e-LMA, (2) mendeskripsikan proses pembelajaran melalui e-LMA, (3) membuat profil, dan menganalisis pemahaman konsep vektor siswa dan kinematika setelah implementasi e-LMA. Pembelajaran berbantuan e-LMA dengan mengintegrasikan materi dan tugas dengan software GeoGebra dapat meningkatkan pemahaman konsep vektor dan kinematika.
\end{abstract}

Kata Kunci: e-LMA, Geogebra, Vector, Kinematics

How to Cite: Handhika, J., Sasono, M. (2021). Using of Geogebra Software to Improve Understanding of Vector and Kinematic Concepts In Online Physics Course. Jurnal Pendidikan Fisika dan Keilmuan (JPFK), 7(1), 1-12. doi: http://doi.org/10.25273/jpfk.v7i1.8619 


\section{Introduction}

In physics courses, there are study materials: vector analysis (Barniol \& Zavala, 2014) and kinematics. These two topics are closely related to each other. Physics consists of vector and scalar quantities. Kinematics material also discusses the magnitude of distance, displacement, velocity, and speed. In addition to kinematics, vector material is also related to other physics materials that form the basis for advanced physics learning(Bollen et al., 2017; Nguyen \& Meltzer, 2003).

Vector material is difficult for students to complete because they do not understand the language of mathematics (Muhsina et al., 2015). Previous research provides information that students have difficulty distinguishing between distance and displacement, speed and velocity (J Handhika et al., 2018; Handhika et al., 2017; Handhika et al., 2019; Jeffry Handhika et al., 2018). Students are also wrong in adding two-dimensional vectors (Heckler \& Scaife, 2015; Sirait \& Oktavianty, 2017). They cannot describe and decompose vectors into their components and equate dot and cross operations. Another reason is that the material presented by the facilitator is not given sequentially (Muhsina et al., 2015). They partially learn the concept of vectors and impact students' misconceptions about the concepts of kinematics and force (Liu \& Fang, 2016).

The results of interviews with students who have taken fundamental physics courses provide information that errors in solving vector operations are because learning at the previous level tends to ignore vectors and then equate two quantities (vectors and scalars) in solving problems. This result is supported by research that reveals that some students ignore the vector direction(Fauzi et al., 2017). The solutions are implemented, among others, by applying a learning model that can stimulate students to evaluate the concept by providing cognitive conflict (Handhika et al., 2015; Handhika et al., 2014). The use of media developed by (Mueanploy, 2015; Nikmah et al., 2019).

Models and media can improve understanding of vector concepts, but real media takes a long time both in implementation and manufacture. An effective and efficient media is needed to teach vector and kinematics concepts. The development of information and communication technology in the digital era provides these facilities through hardware and software. Software that can use is Maple and GeoGebra. In mathematics, Geogebra software can use to introducing mathematical operations. For example (Ponce Campuzano et al., 2019) uses this software to dynamically describe the main concepts in Vector Calculus (Ibibo \& Tubona, 2019), teach geometry concepts, and improve mathematics learning outcomes (Zulnaidi et al., 2020). Not only in learning mathematics but also for learning physics (Marciuc et al., 2016) on motion material in a uniform gravitational field and concretizing abstract physics concepts (Yüksel \& Çıldır, 2015).

This article describes how to improve understanding of vector concepts and kinematics with GeoGebra software through e-LMA (electronic learning at PGRI Madiun University). Geogebra software is free software provided by the https://www.geogebra.org page. This software can explain vector operations using drawing methods more easily, quickly, precisely, and accurately. For more details, consider the following example of adding three vectors using the Geogabra software Figure 1 below: 


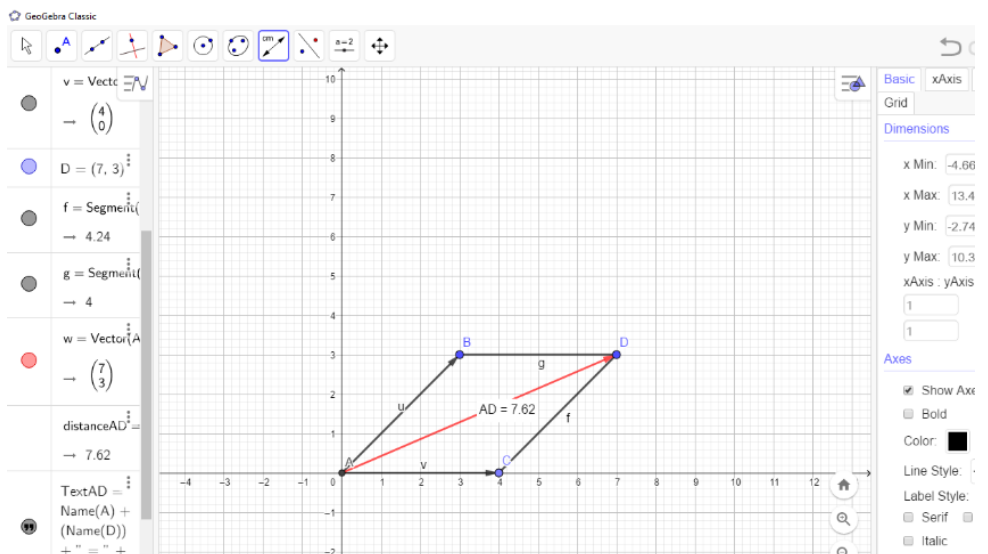

Figure 1. Magnitude Two Vector Using GeoGebra

In Figure 1, the GeoGebra software can determine quickly and accurately the resultant vectors $\vec{u}$ and $\vec{v}$ Using the image method. The resultant of two vectors are represented in vector $(\overrightarrow{A D})$ and the vector magnitude is 7.62. GeoGebra software can quickly solve the results of the three vectors by drawing methods. In kinematics have a vector quantity so that the explanation of kinematics material can also be integrated with this software.

Previous research only used Geogebra software to improve students' understanding of physics concepts and mathematical abilities (Marciuc et al., 2016; Oktaria et al., 2016; Yüksel \& Çıldır, 2015). Not yet specifically reviewing content and integration with e-learning. In this research, Geogebra software integrated with UNIPMA e-learning (e-LMA). This gives students the freedom to study material and use the software anytime and anywhere, interaction between students and lecturers during synchronous and asynchronous discussions to reveal their understanding of kinematics material, assign tasks using software and provide direct feedback to students.

\section{Methods}

The method used in this research is descriptive by describing the learning process carried out through e-LMA. The kinematics concept is limited to position, distance, displacement, the magnitude of displacement, velocity, and acceleration. The descriptive research conducted on four students who took fundamental physics for the 2019/2020 academic year. Data collection techniques through documentation, tests, and interviews. The following research steps (Figure 2):

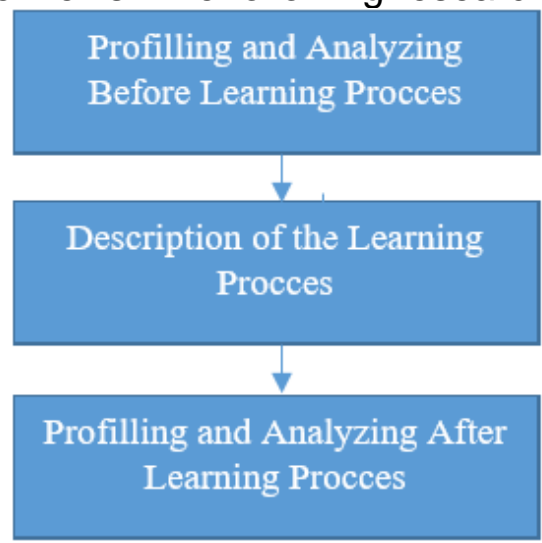

Figure 2. Research Steps 
Explanation of Figure 2 is as follows: 1) create a profile and analyze the understanding of vector and kinematic concepts before implementing e-LMA, (2) describe the learning process through e-LMA, (3) create a profile and analyze the understanding of vector and kinematic concepts after e-LMA implementation. The research conducted on four students who took fundamental physics for the $2019 / 2020$ academic year. The test instrument used in this study consisted of 4 items in descriptions that experts had validated. - Data analysis is expressed as a percentage of the results of understanding.

\section{RESULTS AND DISCUSSION}

The results of the research presented include (1) a profile of understanding vector concepts and kinematics before the implementation of e-LMA, (2) an overview of the learning process through e-LMA, (3) a profile of understanding vector concepts and kinematics after the implementation of e-LMA. The results of this research describe as follows:

1. Profile and analysis of understanding of vector concepts and kinematics before implementing e-LMA

Before the implementation of e-LMA, students still did not understand the concept of vector and kinematics well. The concept of vector quantities is not well understood. Problems related to vector addition with the image method are not solved, cannot distinguish cross and dot multiplication. The concepts of position, distance, displacement, and magnitude of displacement, velocity, acceleration are not well understood. The initial profile of understanding of each student $d$ (denoted by $1,2,3,4$ ) is present in table 1 below:

Table 1 Students' initial understanding of the concepts of Vector and Kinematics

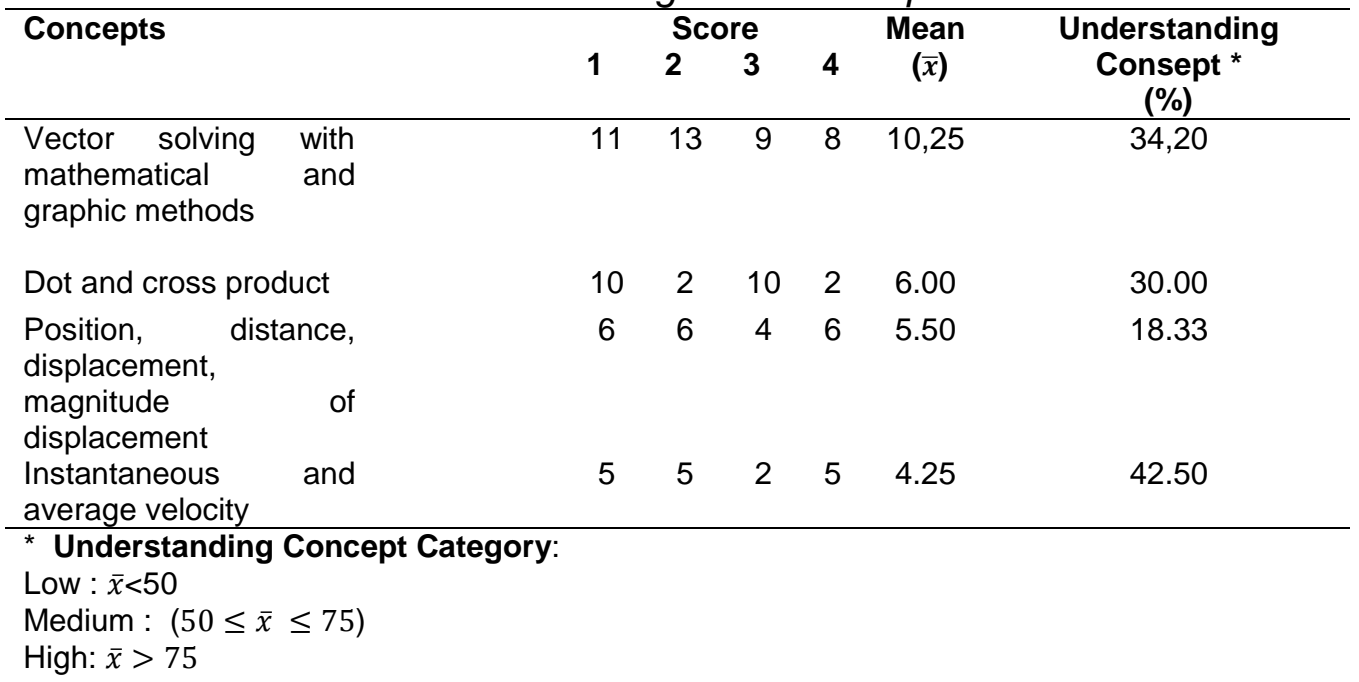

The understanding concept for all component vectors is in the low category (less than 50\%). These results provide information about students' understanding of vector concepts and kinematics is still low. The results of interviews with students show that they only memorize equations, then apply them to the same problem or solve the same problem. Students also revealed that they have the same conception, namely distance, magnitude of displacement, and displacement, velocity, and velocity are also the same. The omission of vector symbols is one of the contributing factors. (Fig.3). 


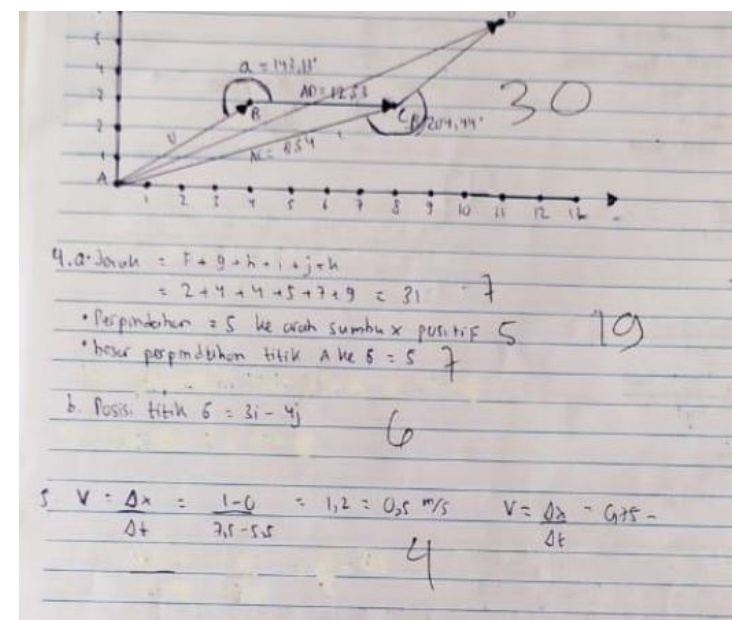

Figure 3. Student Response: Ignoring Vector Symbol

In Figure 3, it can see that students ignore vector symbols in determining displacement so that an error occurs when determining velocity. Understanding the concept of vectors needs to be emphasized to students. Figure 4 shows that students equate the concepts of displacement and distance.

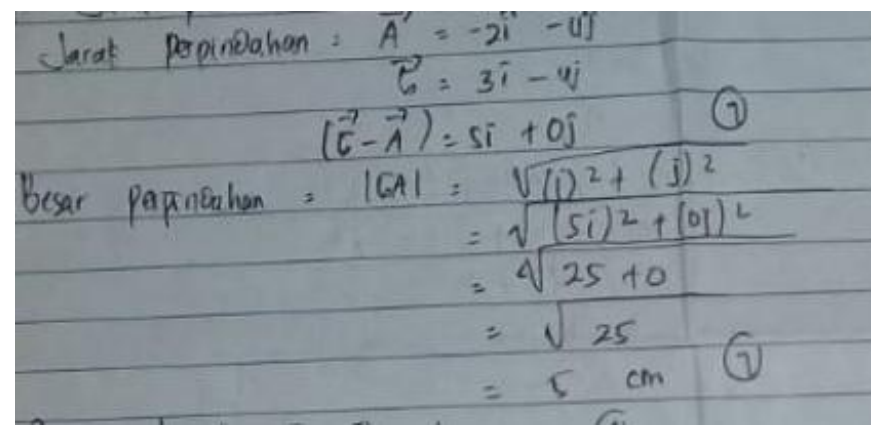

Figure 4. Student Response: Equating the Concepts of Displacement and Distance.

The results of interviews with students obtained information that distance and displacement were difficult to distinguish according to their understanding. They understand this prejudice since they were in junior high school. After going through various learning experiences, students get the right results even though, at first, some steps are not quite right. In Figure 5, students have difficulty in completing cross and dot multiplication.

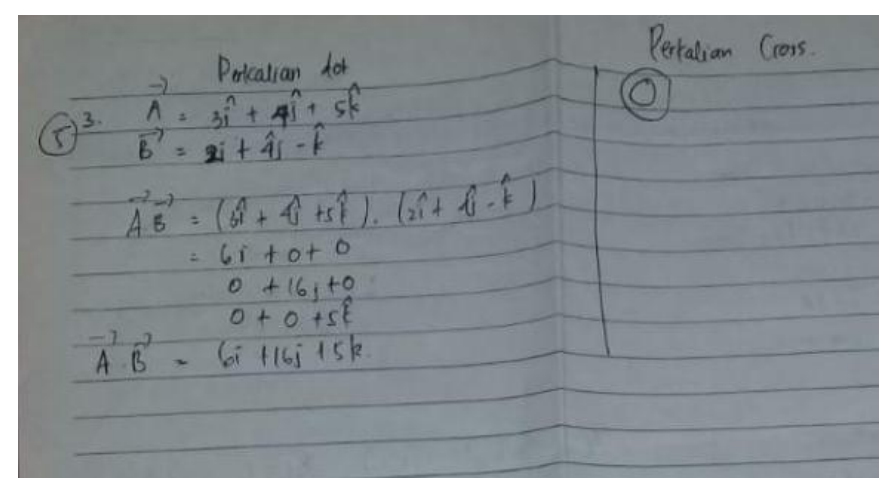

Figure 5a Student Response: Dot and Cross Operations I 


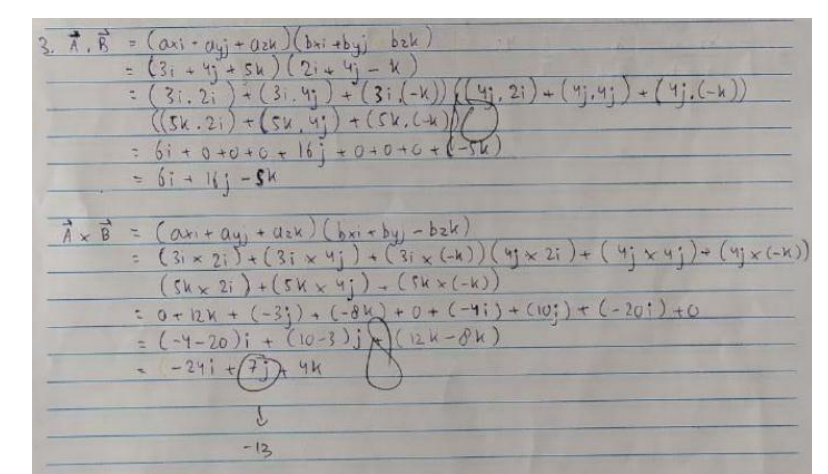

Figure 5b Student Response: Dot and Cross Operations II

In Figure 5a, students cannot complete cross multiplication, assuming that the completion of vector multiplication is the same as algebraic multiplication in general. In contrast, in Figure 5b, students experience errors in completing algebraic addition. Student responses in Figure $5 \mathrm{~b}$ can be achieved by strengthening students' ability to solve mathematical equations. Student responses in Figure $5 \mathrm{a}$ show that strengthening the concept of vectors is very important in addition to solving mathematical algebra. These results support previous research (Handhika et al., 2017; Jeffry Handhika et al., 2018). Students also do not understand the relationship between vector material and kinematics. Students do not know the concept of vectors used to analyze kinematics. Ignoring vector symbols impacts students' errors in identifying position, distance, displacement, and the magnitude of the displacement.

Students need to strengthen the language of mathematics and vector material before studying advanced physics material, such as kinematics and dynamics. Muhsina et al. (2015) recommend that material arrangement is very important, especially content about vectors. Other physics concepts can be understood if you have mastered the vector concept (Ritonga, 2014); strengthening vector material is important. Giving vector concepts with various representations through GeoGebra software is the right way to strengthen vector concepts.

\section{Description of the Learning Process through e-LMA}

In e-LMA learning, the first activity is to synthesize and analyze various sources of the concepts. Instructions on the analysis and synthesis of concepts have been present. Students upload the results of the analysis and synthesis into the LMS system. The results of the analysis and synthesis by students provide an overview of the initial conceptions possessed by students as the basis for lecturers in providing unit questions in discussion forums. Then the activity continued by analyzing the material presented in various forms of presentation (text, video, simulation).

In this activity, students are invited to analyze and synthesize material from textbooks and videos, then synthesize the results of simulations that are carried out independently). The results of the activities are presented in an online discussion. The next step is to synergize students' arguments to get the right knowledge. To solve the problem in step (1) e-LMA is equipped with an explanation from the lecturer in the form of PowerPoint and video presentations. This task also includes the use of GeoGebra in solving vector and kinematics problems (Figure 6). An online discussion forum is also available (Figure 7). By 
using e-LMA students are expected to be able to obtain information anytime and anywhere.

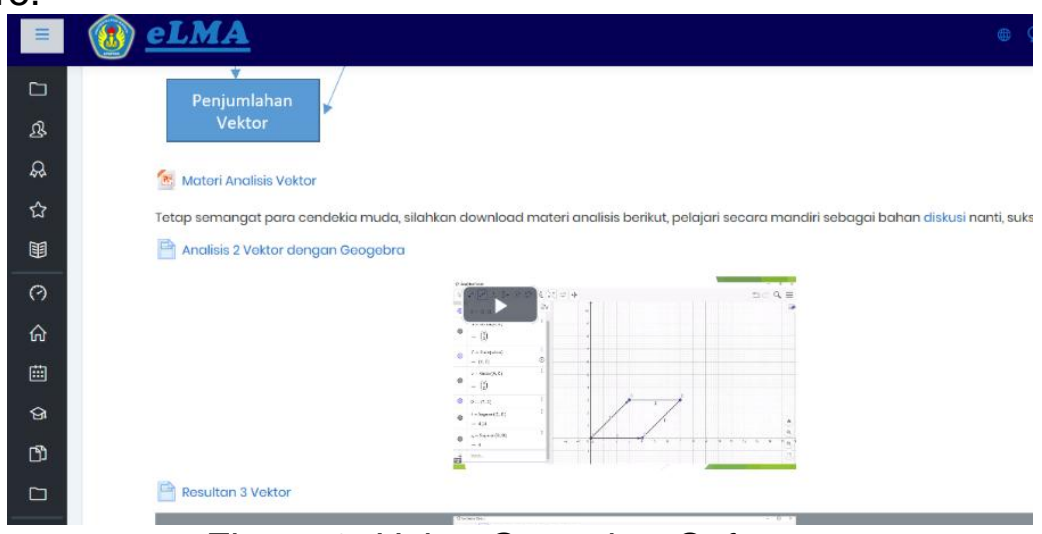

Figure 6. Using Geogebra Software

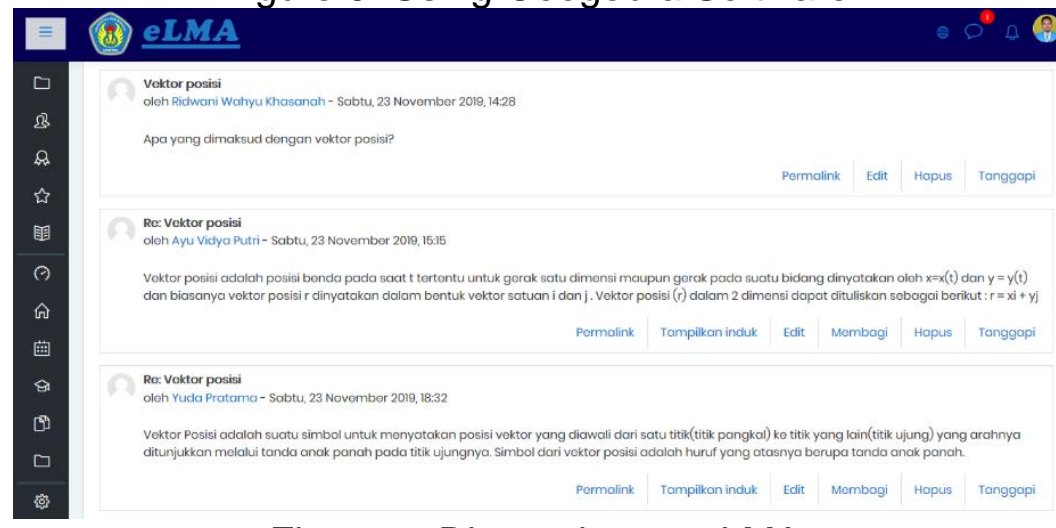

Figure 7. Discussion on eLMA

The material presented in the form of power points and videos about using GeoGebra software helps students complete vector algebra operations. In addition, students know the concepts of position, distance, displacement, and the magnitude of displacement in mathematical presentations. Discussions can occur between lecturers and students, as well as students and lecturers (figure 7). Students can ask questions, and other friends provide feedback.

Learning through e-LMA begins by providing information related to university contracts and learning outcomes. Lecture contracts are discussed through online forums. In this application, offline lecture contracts are discussed because many students still do not understand the use of e-LMA. After reviewing the lecture contract and studying learning achievements, students are asked to consider the material in the e-LMA, which is presented in the form of power points, and solve the problems presented in the discussion forum. Video material is also presented. With the material presented in the form of videos, students can review the content presented repeatedly and not be limited by time. A student also revealed that they could take notes without fear of being left behind due to time constraints. During face-to-face learning, students were given the task of solving three resultant vector problems through e-LMA. (3) Profile and analysis of the understanding of vector concepts and kinematics after the application of e-LMA.

Understanding of vector concepts and kinematics after application can be seen in table 2 . 
Table 2. Final Profile Students Understanding Vector and Kinematics Concept

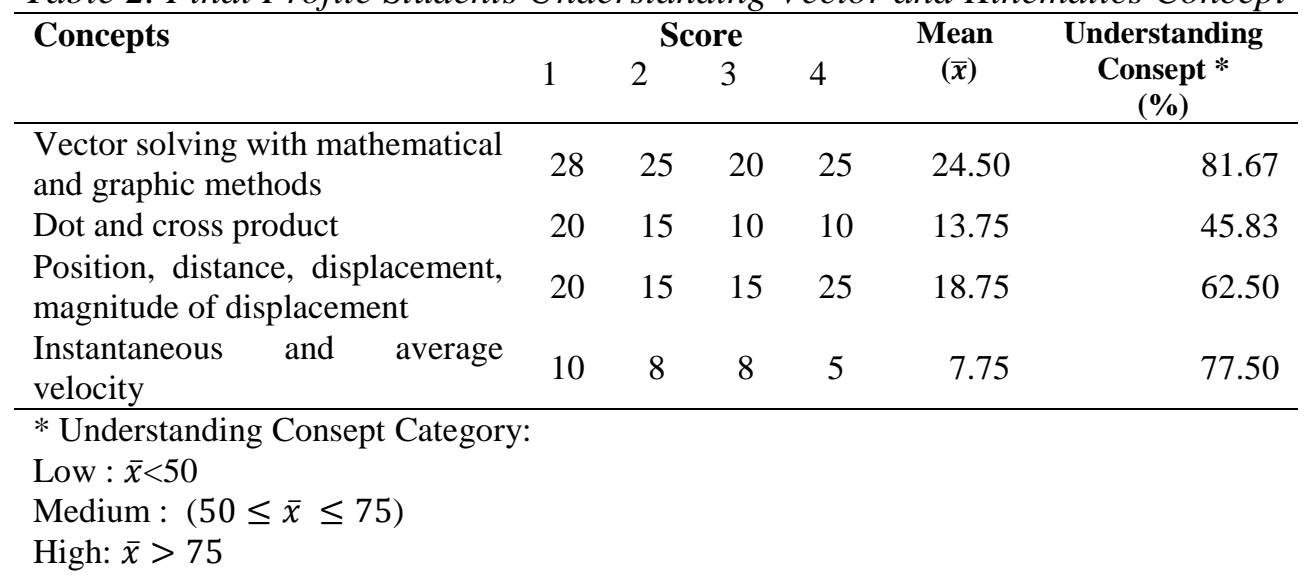

Based on table 2, it can see that the percentage of students' abilities has increased in each component-the amount of increase in each component in table 3.

Table 3 N-Gain Category

\begin{tabular}{|c|c|c|c|}
\hline Konsep & $\begin{array}{l}\text { Initial } \\
\text { Score }\end{array}$ & $\begin{array}{l}\text { Final } \\
\text { Score }\end{array}$ & $\begin{array}{l}\text { Percentage } \\
\text { (Category) }\end{array}$ \\
\hline $\begin{array}{lrr}\text { Vector solving } & \text { with } \\
\text { mathematical and } & \text { graphic } \\
\text { methods } & & \end{array}$ & 34,20 & 81,67 & $\begin{array}{c}72 \% \\
\text { (High) }\end{array}$ \\
\hline Dot and cross product & 30,00 & 45,83 & $\begin{array}{l}23 \% \\
\text { (Low) }\end{array}$ \\
\hline $\begin{array}{l}\text { Position, } \\
\text { displacement, magnitude of } \\
\text { displacement }\end{array}$ & 18,33 & 62,50 & $\begin{array}{l}54 \% \\
\text { (Low) }\end{array}$ \\
\hline $\begin{array}{l}\text { Instantaneous and average } \\
\text { velocity }\end{array}$ & 42,50 & 77,50 & $\begin{array}{l}60 \% \\
\text { (High) }\end{array}$ \\
\hline
\end{tabular}

Based on table 3, all concept components have increased. The highest increase is in vector addition operations, while the lowest increase is in dot and cross multiplication. The problem of learning physics that becomes a challenge is mathematical debate, including vector algebra problems (Chiu, 2016; Harwanto, 2019). In dot and cross vector operations, the students' mistakes discussed are how certain parts are interchanged and have not used the concept of cross and dot multiplication correctly. The students' prior knowledge also issues this requirement. It is not easy to change the concept of students who have been equating dot and cross-multiplication operations. The results Zavala and Barniol (2010) provide information about students who have difficulty differentiating cross-product results and calculating vector quantities. Students also consider dot multiplication between two vectors the same as scalar multiplication (Susiharti \& Ismet, 2017). Students also do not understand the physical meaning of the cross product (Bollen et al., 2017).

It is not easy to change students' conceptions of equating vector quantities with scalars. Vector solutions using mathematical and graphic methods have increased in the high category. This condition is because students can analyze and synthesize the resultant of two and three vectors, both mathematically and graphically. Vector solving with GeoGebra helps students evaluate mathematical solutions.. 
The use of Geogebra makes students interested in trying to create problems and solve them independently. Kim et al. (2021) revealed that graphic presentations could reduce barriers to learning and practicing vector problem solving and make students interested and motivated to manipulate vector problems. The use of GeoGebra software has helped students understand the concept of vectors. GeoGebra helps students facilitate abstract material into concrete in the form of visualization (Yüksel \& Çıldır, 2015).

e-LMA is a UNIPMA e-Learning developed from the UNIPMA e-portfolio, which was modified by giving users the freedom to develop materials in various formats. e-LMA is also given pedagogical strengthening by providing analysis and synthesis activities at each stage. A physics researcher or facilitator has developed the Learning Management System. The location of the novelty is in the pedagogic and instructional elements in presenting learning. The LMS elearning developed by (Wijayanti et al., 2017) focuses on the quality of LMS products. Research (Kurniawan et al.; Mulhayatiah et al., 2019) develops elearning and e-modules by displaying videos and simulations; Research (Krasnova \& Shurygin, 2020) uses blended learning and LMS for physics teachers and makes learning more effective. Recommendations from various studies need to strength related to pedagogical elements. By using eLMA, these conditions can realize.

The e-LMA, integrated with GeoGebra, has novelties related to pedagogical content, not only interactive materials and questions. Before learning takes place, students are direct to analyze and synthesize from various sources by uploading review assignments and then analyzing in various presentations (videos, textbooks, and simulations). At the material analysis stage, students evaluate concepts in videos and textbooks by performing simulations with GeoGebra software independently. Learning using e-LMA can be done through blended learning. Based on interviews with students after a joint discussion regarding the problems they solve, students quickly find errors in working on the questions. In research (Saputra et al., 2019), students had difficulties solving problems with different representations. These problems can resolve by presenting different representations of material, accompanied by analysis and synthesis of information sources and simulations.

Students revealed that they often get confused in completing cross and dot multiplication in certain parts because of doubts (forgetting). These results are in accordance with research(Barniol \& Zavala, 2016). This information reinforces that the concept of dot and cross-multiplication has not been meaningful. The media presented has not been able to foster cognitive conflicts that can stimulate students to have a deeper knowledge of vector operations.

It is recommended to give discussion questions with a larger proportion to strengthen the differentiation of dot and cross-multiplication operations, thereby causing cognitive conflicts by asking students to correct their answers. The presentation of vectors in the form of graphics provides a visual appeal that can make students have an emotional connection with the information conveyed. It will be remembered and understood, which is related to the human factor, where information can be easily recognized and stored in long-term memory (Adi \& Ariesta, 2019). 


\section{CONCLUSION}

Based on the discussion and analysis, it can conclude that e-LMA assisted learning by integrating materials and tasks with GeoGebra software can improve understanding of vector concepts and kinematics. Vector addition operations with graphical and mathematical methods have increased because they use graphic and algebraic methods. Students can synthesize results with graphs so that if an error occurs, they can make corrections directly. GeoGebra software also makes it easy for students to complete vector addition operations in a relatively fast time compared to manual drawing on paper.

The concepts of position, distance, displacement, and magnitude of displacement and the concepts of instantaneous and average velocity have increased in the medium category. Geogebra software on e-LMA also makes it easier for students to distinguish the concepts of position, position vector, distance, displacement, and the magnitude of displacement. In the dot and cross product, students experience an increase in the low category. Learning in e-LMA does not yet contain content that can trigger cognitive conflicts; The indication can see from the students' doubts in solving problems, reversed in completing dot and cross multiplication.

\section{References}

Adi, D., \& Ariesta, I. (2019). Infographic in relation to the human information-processing system and its effectiveness to deliver complex information. Journal of Physics: Conference Series,

Barniol, P., \& Zavala, G. (2014). Test of understanding of vectors: A reliable multiplechoice vector concept test. Physical Review Special Topics-Physics Education Research, 10(1), 010121.

Barniol, P., \& Zavala, G. (2016). A tutorial worksheet to help students develop the ability to interpret the dot product as a projection. Eurasia Journal of Mathematics, Science and Technology Education, 12(9), 2387-2398.

Bollen, L., van Kampen, P., Baily, C., Kelly, M., \& De Cock, M. (2017). Student difficulties regarding symbolic and graphical representations of vector fields. Physical Review Physics Education Research, 13(2), 020109.

Chiu, M.-S. (2016). The challenge of learning physics before mathematics: A case study of curriculum change in Taiwan. Research in science education, 46(6), 767-786.

Fauzi, A., Kawuri, K. R., \& Pratiwi, R. (2017). Multi-perspective views of students' difficulties with one-dimensional vector and two-dimensional vector. Journal of Physics: Conference Series,

Handhika, J., Cari, C., Sunarno, W., Suparmi, A., \& Kurniadi, E. (2018). The influence of project-based learning on the student conception about kinematics and critical thinking skills. Journal of Physics: Conference Series,

Handhika, J., Cari, C., Suparmi, A., \& Sunarno, W. (2015). Exsternal representation to overcome misconception in physics. International Conference on Mathematics, Science, and Education, 
Handhika, J., Cari, C., Suparmi, A., \& Sunarno, W. (2017). The influence of intuition and communication language in generating student conceptions. Journal of Physics: Conference Series,

Handhika, J., Istiantara, D., \& Astuti, S. (2019). Using graphical presentation to reveals the student's conception of kinematics. Journal of Physics: Conference Series,

Handhika, J., Kurniadi, E., \& Muda, I. (2014). Pengembangan Media Pembelajaran Bermuatan Konflik Kognitif Untuk Mengurangi Dugaan Miskonsepsi Pada Matakuliah Fisika Dasar. Jurnal Materi dan Pembelajaran Fisika, 4(2).

Handhika, J., Mayasari, T., Huriawati, F., Yusro, A. C., \& Sasono, M. (2018). The Students Conception About Kinematics.

Harwanto, U. N. (2019). WHAT MAKES INTRODUCTORY PHYSICS DIFFICULT? Jurnal Saintika Unpam: Jurnal Sains dan Matematika Unpam, 2(1), 28-37.

Heckler, A. F., \& Scaife, T. M. (2015). Adding and subtracting vectors: The problem with the arrow representation. Physical Review Special Topics-Physics Education Research, 11(1), 010101.

Ibibo, C.-O. G., \& Tubona, G. (2019). Student“ perception and performance across ability levels on GeoGebra software usage in learning of circle geometry.

Kim, J.-H., Oh, M. S., \& Kim, K.-Y. (2021). Boosting vector calculus with the graphical notation. American journal of physics, 89(2), 200-209.

Krasnova, L. A., \& Shurygin, V. Y. (2020). Blended learning of physics in the context of the professional development of teachers. International Journal of Technology Enhanced Learning, 12(1), 38-52.

Kurniawan, F. A., Sulhadi, S., \& Yulianto, A. Development of Web Based Learning Material in Physics Subject for Kalor and Temperature Material. INDONESIAN JOURNAL OF APPLIED PHYSICS, 5(02), 57-64.

Liu, G., \& Fang, N. (2016). Student misconceptions about force and acceleration in physics and engineering mechanics education. International Journal of Engineering Education, 32(1), 19-29.

Marciuc, D., Miron, C., \& Barna, E. S. (2016). Using GeoGebra and Vpython software for teaching motion in a uniform gravitational field. Romanian Reports in Physics, 68(4), 1603-1620.

Mueanploy, W. (2015). Study of the vector product using three dimensions vector card of engineering in Pathumwan Institute of Technology. Journal of Physics: Conference Series,

Muhsina, M., Werdhiana, I. K., \& Pasaribu, M. (2015). Pengaruh Urutan Pemberian Materi Pembelajaran (Sequenced) Dengan Model Fragmented dan Model Connected Terhadap Hasil Belajar Siswa Pada Konsep Vektor Di SMA Negeri 1 Palu. Mitra Sains, 3(2), 17-23. 
Mulhayatiah, D., Purwanti, P., Setya, W., Suhendi, H. Y., Kariadinata, R., \& Hartini, S. (2019). The impact of digital learning module in improving students' problemsolving skills. Jurnal IImiah Pendidikan Fisika Al-Biruni, 8(1), 11-22.

Nguyen, N.-L., \& Meltzer, D. E. (2003). Initial understanding of vector concepts among students in introductory physics courses. American journal of physics, 71(6), 630638.

Nikmah, F., Subali, B., \& Sumpono, I. (2019). Desain Alat Peraga Vektor Resultan Gaya untuk Siswa Sekolah Menengah Atas (SMA). UPEJ Unnes Physics Education Journal, 8(2), 152-161.

Oktaria, M., Alam, A. K., \& Sulistiawati, S. (2016). Penggunaan Media Software GeoGebra untuk Meningkatkan Kemampuan Representasi Matematis Siswa SMP Kelas VIII. Kreano, Jurnal Matematika Kreatif-Inovatif, 7(1), 99-107.

Ponce Campuzano, J., Roberts, A., Matthews, K., Wegener, M., Kenny, E., \& Mclntyre, T. (2019). Dynamic visualization of line integrals of vector fields: A didactic proposal. International Journal of Mathematical Education in Science and Technology, 50(6), 934-949.

Ritonga, W. (2014). Analisis Penguasaan Konsep Mahasiswa Prodi Fisika FMIPA Unimed pada Materi Vektor. Unimed: Medan.

Saputra, A. T., Jumadi, J., Paramitha, D. W., \& Sarah, S. (2019). Problem-solving approach in multiple representations of qualitative and quantitative problems in kinematics motion. Jurnal Ilmiah Pendidikan Fisika Al-Biruni, 8(1), 89-98.

Sirait, J. H., \& Oktavianty, E. (2017). Analysis of pre-service physics teachers' understanding of vectors and forces. Journal of Turkish Science Education, 14(2), 82-95.

Susiharti, S., \& Ismet, I. (2017). Studi Kesalahan Siswa dalam Menyelesaikan Soal-Soal Vektor di SMA Negeri 1 Inderalaya. Jurnal Inovasi dan Pembelajaran Fisika, 4(1), 100-108.

Wijayanti, W., Maharta, N., \& Suana, W. (2017). Pengembangan perangkat blended learning berbasis learning management system pada materi listrik dinamis. Jurnal Ilmiah Pendidikan Fisika Al-Biruni, 6(1), 1-12.

Yüksel, N. S., \& Çıldır, S. (2015). The impacts of dynamic geometry software on graphing abilities of prospective physics teachers: Geogebra sample. International Journal of Physics \& Chemistry Education, 7(1), 46-61.

Zavala, G., \& Barniol, P. (2010). Students' understanding of the concepts of vector components and vector products. AIP Conference Proceedings,

Zulnaidi, H., Oktavika, E., \& Hidayat, R. (2020). Effect of use of GeoGebra on achievement of high school mathematics students. Education and Information Technologies, 25(1), 51-72. 